\title{
The Changing Management of Colonoscopy-Associated Perforations
}

\author{
David L. Carr-Locke \\ The Endoscopy Institute, Brigham and Women's Hospital, Boston, Mass., USA
}

During the pre-endoscopy consent process, patients are informed that the principle risk of colonoscopy is perforation with an expected overall incidence of about 1 in 1,000 , but with a range of about 1 in 2,000 for diagnostic procedures to 1 in 600 for therapeutic procedures [1-8]. If institutional data are known, these should be quoted (1 in 3,300 for diagnostic and 1 in 2,500 for therapeutic for our unit). The expected consequence of most major perforations is surgery, which may range from laparoscopic or open primary closure to resection with or without defunctioning colostomy or ileostomy. This means that an elective diagnostic colonoscopy carries a risk of about 1 in 1,600 for major surgery, and a therapeutic colonoscopy one of about 1 in 500 .

There has been growing use of endoscopic accessories, especially clips, for closing perforations of the gastrointestinal tract with increasing success [9-11]. Should this then become the standard approach for perforations recognized during or shortly after the index procedure? In this issue, Kang et al. [12] report a retrospective series of 53 iatrogenic colonic perforations seen over a 7-year period at the Seoul National University College of Medicine. This represented an overall perforation rate of $0.12 \%$ ( 1 in 833$)$, but rates of $0.07 \%$ ( 1 in 1,452) for diagnostic procedures and $0.4 \%$ ( 1 in 251 ) for therapeutic procedures. Although 34 (64\%) were treated surgically, the remaining 19 patients (36\%) were treated conservatively, and in 7 of 9 , in whom clips were used to close the defect, this was successful. There were no deaths.
In a stable patient with a 'clean' colon, a perforation recognized during colonoscopy (or within a few hours while the preparation is still effective) should be given the chance of endoscopic closure by the primary endoscopist or a colleague more expert in therapeutic techniques. Moving the patient to a fluoroscopy room may assist in confirming successful closure by the injection of radiographic contrast. The technical challenges of endoscopic closure are that perforations associated with diagnostic colonoscopy tend to be large tears, and those delayed perforations associated with therapeutic colonoscopy resulting from cautery may not provide good tissue for apposition. The process may also take too long to close with current devices, during which time air insufflation is necessary to maintain endoscopic visualization. Carbon dioxide is the preferred insufflating gas in this situation because of its rapid absorption.

Correct clip technique is important. Depending on the shape and size of the defect to be closed, it is often easier to begin mucosal clip placement at the extreme ends or just outside of the defect. Sequential clip deployment towards the center or towards the widest part of the defect can then proceed, as this will make the distance between the edges to be apposed closer and easier to grasp. Remember that clips can remain in place for many weeks or months and are not MRI compatible. If an MRI becomes necessary, a plain radiograph must be taken to ensure elimination of the clips first.

\section{KARGER}

Fax +4161306 1234 E-Mail karger@karger.ch www.karger.com
(C) 2009 S. Karger AG, Basel

0012-2823/08/0784-0216\$24.50/0

Accessible online at:

www.karger.com/dig
David L. Carr-Locke, MD

The Endoscopy Institute, Brigham and Women's Hospital

One Brigham Circle

Boston, MA 02115 (USA)

Tel. +1 617732 7414, Fax +1 617264 5171, E-Mail dcarrlocke@partners.org 
Since deliberate perforation is an integral part of Natural Orifice Transluminal Endoscopic Surgery (NOTES) procedures, one of the unexpected benefits of NOTES research is the potential development of gastrointestinal tract mural closure techniques and devices [13]. Transcolonic NOTES has also demonstrated something known, but not always appreciated: namely, that the distended colon wall is remarkably thin and easily perforated. It is somewhat surprising that perforations in humans are as infrequent as they are, and this is a testament to the skill, modern techniques and care taken by trained endoscopists. Unknown variations in wall integrity and thickness and fixation of the colon, especially the sigmoid, from prior intra-abdominal surgery or disease, present additional hazards.

So what lessons have we learned concerning perforation of the colon associated with colonoscopy? First, do not struggle with a difficult diagnostic colonoscopy in the presence of a poor preparation, since perforation will result in significant contamination and increase the likelihood of surgery. Second, if a perforation is recognized intra-procedurally, make an attempt to close it endoscopically. Third, if the patient is symptomatic after the procedure, make the diagnosis of perforation early and consider endoscopic therapy if the preparation is still adequate, remembering that for diagnostic procedures the sigmoid colon is the most common site of perforation. Fourth, if the colon is no longer clean enough to intervene endoscopically, involve a laparoscopic surgeon early since primary laparoscopic closure may be possible [14]. Fifth, surgery is always required for significant peritonitis or an unstable patient. Sixth, educate your patients to return immediately when symptoms appear.

\section{References}

1 Luning TH, Keemers-Gels ME, Barendregt WB, Tan AC, Rosman C: Colonoscopic perforations: a review of 30,366 patients. Surg Endosc 2007;21:994-997.

$\checkmark 2$ Tulchinsky H, Madhala-Givon O, Wasserberg N, Lelcuk S, Niv Y: Incidence and management of colonoscopic perforations: 8 years' experience. World J Gastroenterol 2006;12:4211-4213.

3 IqbalCW, Cullinane DC, Schiller HJ, Sawyer MD, Zietlow SP, Farley DR: Surgical management and outcomes of 165 colonoscopic perforations from a single institution. Arch Surg 2008;143:701-707.

$\checkmark 4$ Kim DH, Pickhardt PJ, Taylor AJ, Leing WK, Winter TC, Hinshaw JL, Gopal DV, Reichelderfer M, Hsu RH, Pfau PR: CT colonography versus colonoscopy for the detection of advanced neoplasia. N Engl J Med 2007;357:1403-1412.

5 Avgerinos DV, Llaguna OH, Lo AY, Leitman IM: Evolving management of colonoscopic perforations. Gastrointest Surg 2008;12: 1783-1789.
-6 Garcia Martinez MT, Ruano Poblandor A, Galan Raposo L, Gay Fernandez AM, Casal Nunez JE: Perforation after colonoscopy: our 16-year experience. Rev Esp Enferm Dig 2007;99:588-592.

7 Levin TR, Zhao W, Conell C, Seeff LC, Manninen DL, Shapiro JA, Schulman J: Complications of colonoscopy in an integrated health care delivery system. Ann Int Med 2006;145:880-886.

8 Rathgaber SW, Wick TM: Colonoscopy completion and complication rates in a community gastroenterology practice. Gastrointest Endosc 2006;64:556-562.

9 Fritscher-Ravens A: Iatrogenic colonic perforations: a threat turned into insignificance? Gastrointest Endosc 2007;65:912913.

10 Magdeburg R, Collet P, Post S, Kaehler G: Endoclipping of iatrogenic colonic perforation to avoid surgery. Surg Endosc 2008;22: 1500-1504.
Raju GS, Fritscher-Ravens A, Rothstein RI, Swain P, Gelrud A, Ahmed I, Gomez G, Winny M, Sonnanstine T, Bergstrom M, Park PO: Endoscopic closure of colon perforation compared to surgery in a porcine model: a randomized controlled trial. Gastrointest Endosc 2008;68:324-332.

12 Kang HY, Kang HW, Kim SG, Kim JS, Park KJ, Jung HC, Song IS: Incidence and management of colonoscopic perforations in Korea. Digestion 2008;78:218-223.

13 Schurr MO, Hartmann C, Ho CN, Fleisch C, Kirschniak A: An over-the-scope clip (OTSC) system for closure of iatrogenic colon perforations: results of an experimental survival study in pigs. Endoscopy 2008;40: 584-588.

14 Rumstadt B, Schilling D: Optimizing time management after perforation by colonoscopy results in better outcome for the patients. Hepatogastroenterology 2008;55: 1308-1310. 